\title{
An association between hypocholesterolaemia and colorectal carcinoma in an Irish population
}

\author{
J S O'Rourke, A Johnson, P Collins, J Duignan, D Bouchier-Hayes
}

\begin{abstract}
A group of 114 Irish patients with primary adenocarcinoma of the large bowel had significantly lower serum cholesterol concentrations than an age and sex matched group drawn from the general population. The hypocholesterolaemiac trait was manifest in male and female patients. Rigorous control procedures established that it was neither an artefact of nutritional compromise nor of preoperative bowel preparatory protocols. The data suggested that the appreciable hypocholesterolaemia observed was not influenced by the pathological stage or degree of differentiation of the tumour.
\end{abstract}

The incidence of colorectal carcinoma differs internationally, the highest rates being observed in the urbanised, affluent societies of the industrialised western world. ${ }^{1}$ The western diet, high in animal fat and low in fibre, has been correlated with an increased incidence of colorectal cancer. ${ }^{23}$ It has been postulated that increased dietary animal fats produce excessive amounts of primary bile salts, which are then subsequently degraded by colonic bacteria to potentially carcinogenic secondary bile salts. Populations at risk for the development of large bowel cancer are also generally at higher risk for development of coronary heart disease. Although high serum cholesterol concentrations are predictive of coronary heart disease, ${ }^{6-9}$ controversy exists as to the relation between serum cholesterol and colorectal carcinoma. While some studies indicate a direct or indeed no relation between the serum cholesterol concentration and large bowel cancer, ${ }^{10-12}$ others indicate an inverse relation. ${ }^{13-15}$

These conflicting reports may be the result of inherent differences in lipid metabolism between the various populations studied or may be explained by a tendency to report solely on the occurrence of colorectal cancer, rather than the particular degree of differentiation and progression of these tumours when detected.

The Irish population has a known tendency towards raised cholesterol concentrations, ${ }^{16}$ and it also has one of the highest mortality rates from colorectal carcinoma in the world. ${ }^{17}$ This study aimed to analyse in detail the serum lipid concentrations in patients with primary colorectal carcinoma drawn from such a population, with an evaluation of the influence of tumour activity on altered serum lipid values.

\section{Methods}

A total of 114 consecutive patients $(67$ men and 47 women) who presented to three Dublin hospitals for elective resection of primary sporadic colorectal carcinomas were included in this study. All gave informed consent. The mean (SEM) age for all patients was $66.6(1.01)$ years; it was $66.8(1 \cdot 3)$ years for men and $66.4(1.6)$ years for women. All patients underwent bowel preparation and a fasting regimen before operation. The regimen consisted of a liquid diet for 36 hours, followed by an absolute fast for a further 12 hours. During the preparatory period a combination of purgation and rectal washouts was performed until the bowel was considered 'clear' of gross faecal residue.

Ten $\mathrm{ml}$ of venous blood were obtained before surgery. The clotted sample was centrifuged at $3000 \mathrm{rpm}$ for 10 minutes and the serum separated. One $\mathrm{ml}$ was used for lipid analysis and the remainder for estimations of serum albumin and retinol binding protein concentrations. The normal laboratory ranges for serum albumin and retinol binding proteins were $35-45 \mathrm{~g} / 1$ and 1.9 $8.0 \mathrm{mg} / \mathrm{dl}$ respectively. In the assessment of the nutritional status of preoperative patients, the predictive validity of the serum albumin concentration (with its half-life $=19$ days) is greatly enhanced when combined with a plasma protein with a short half-life, such as retinol binding protein (half-life $=2$ days). ${ }^{18-20}$ Relevant preoperative clinical details were recorded as well as routine laboratory investigations (full blood count, hepatic and renal function tests) and radiological assessments (chest radiographs, abdominal computed tomography, and ultrasound scans).

Tumour staging was dependent upon the histological features and the clinical findings at the time of resection. The Astler and Coller modifications of Dukes's staging were used. ${ }^{212}$ Tumours were assigned stage $\mathrm{D}$ if there was any evidence of distant disease spread. The distribution of the tumours is shown in Table I - 56 patients had tumours confined to the bowel wall or just penetrating it (stage A or B) and the remaining 58 had advanced tumours with either locoregional nodal involvement or distant metastases (stage C or D). The degree of tumour differentiation was also assessed using standard criteria. ${ }^{23}$ Most tumours $78(68 \cdot 4) \%$ were moderately differentiated, $21(18 \cdot 4) \%$ were well differentiated, and $15(13 \cdot 2) \%$ poorly differentiated (Table I).

To investigate the possibility of bias arising within the serum lipid values as a result of the preoperative bowel preparation and fasting, a further group of 38 patients ( 13 men, 25 women) with normal colonoscopy findings served as controls. This control group had no abnormalities known to interfere with serum lipid concentrations, and each patient underwent the same fasting and colonic preparation as the cancer 
TABLE I The distribution of tumours according to pathological stage and grade

\begin{tabular}{|c|c|c|c|c|c|c|}
\hline \multirow[b]{3}{*}{$\begin{array}{l}\text { Tumour } \\
\text { stage }\end{array}$} & \multicolumn{6}{|c|}{ Tumour differentiation } \\
\hline & \multicolumn{3}{|l|}{ Men } & \multicolumn{3}{|l|}{ Women } \\
\hline & $\begin{array}{l}\text { Poor } \\
\text { No }(\%)\end{array}$ & $\begin{array}{l}\text { Moderate } \\
\text { No }(\%)\end{array}$ & $\begin{array}{l}\text { Well } \\
\text { No }(\%)\end{array}$ & $\begin{array}{l}\text { Poor } \\
\text { No }(\%)\end{array}$ & $\begin{array}{l}\text { Moderate } \\
\text { No }(\%)\end{array}$ & $\begin{array}{l}\text { Well } \\
\text { No(\%) }\end{array}$ \\
\hline $\begin{array}{l}\text { A } \\
\text { B } \\
\text { C } \\
\text { D } \\
\text { Total }\end{array}$ & $\begin{array}{l}0 \\
1(14 \cdot 3) \\
5(71 \cdot 4) \\
1(14 \cdot 3) \\
7(100)\end{array}$ & $\begin{array}{l}0 \\
27(57 \cdot 5) \\
8(17 \cdot 0) \\
12(25 \cdot 5) \\
47(100)\end{array}$ & $\begin{array}{c}3(23 \cdot 1) \\
7(53 \cdot 8) \\
0 \\
3(23 \cdot 1) \\
13(100)\end{array}$ & $\begin{array}{l}0 \\
0 \\
7(87 \cdot 5) \\
1(12 \cdot 5) \\
8(100)\end{array}$ & $\begin{array}{c}0 \\
12(38 \cdot 7) \\
12(38 \cdot 7) \\
7(22 \cdot 6) \\
31(100)\end{array}$ & $\begin{array}{l}0 \\
6(75) \\
0 \\
2(25) \\
8(100)\end{array}$ \\
\hline
\end{tabular}

patients. The mean (SEM) age of the control group was $64 \cdot 7(2 \cdot 2)$ years (men $61 \cdot 2(3 \cdot 4)$ years, women: $65.8(3.2)$ years), which did not differ significantly from the colorectal cancer group.

Serum was also obtained from a further 23 subjects (10 men, 13 women) who were having benign adenomas removed at laparotomy or colonoscopy. Eleven ( 6 men, 5 women) of these subjects had tubular adenomatous polyps, $8(2$ men, 6 women) had tubovillous polyps, and 4 ( 2 men, 2 women) had villous adenomas. These patients underwent a bowel preparation and fasting regimen similar to the other patients in this study. The mean age for men was $63 \cdot 4$ years, and for women $65 \cdot 5$ years.

Serum triglyceride, total cholesterol, low density lipoprotein (LDL) cholesterol, and high density lipoprotein (HDL) cholesterol were measured using kits provided by Boehringer Mannheim GmbH Diagnostica. Triglycerides were measured as described by Wahlefeld..$^{24}$ Total cholesterol concentrations were estimated using an enzymatic colorimetric method described by Roschlau, ${ }^{25}$ while the assay of the HDL

TABLE II Mean (SEM) serum lipid concentrations (mmol/l) in the three groups

\begin{tabular}{llll}
\hline & $\begin{array}{l}\text { Cancer } \\
\text { patients }\end{array}$ & $\begin{array}{l}\text { Polyp } \\
\text { patients }\end{array}$ & Controls \\
\hline Men: & $\mathrm{n}=67$ & $\mathrm{n}=10$ & $\mathrm{n}=13$ \\
Triglyceride & $1 \cdot 17(0 \cdot 06)$ & $1 \cdot 38(0 \cdot 22)$ & $1 \cdot 55(0 \cdot 24)$ \\
Total cholesterol & $3 \cdot 79(0 \cdot 12) \dagger$ & $5 \cdot 00(0 \cdot 43)$ & $4 \cdot 83(0 \cdot 14)$ \\
LDL cholesterol & $2 \cdot 56(0 \cdot 10)^{\star}$ & $3 \cdot 24(0 \cdot 28)$ & $3 \cdot 10(0 \cdot 19)$ \\
HDL cholesterol & $0 \cdot 70(0 \cdot 03) \dagger$ & $1 \cdot 14(0 \cdot 15)$ & $1 \cdot 04(0 \cdot 08)$ \\
Women: & $\mathrm{n}=47$ & $\mathrm{n}=13$ & $\mathrm{n}=25$ \\
Triglyceride & $1 \cdot 34(0 \cdot 08)$ & $1 \cdot 14(0 \cdot 16)$ & $1 \cdot 20(0 \cdot 12)$ \\
Total cholesterol & $4 \cdot 35(0 \cdot 13) \ddagger$ & $5 \cdot 92(0 \cdot 33)^{\star}$ & $5 \cdot 19(0 \cdot 17)$ \\
LDL cholesterol & $2 \cdot 95(0 \cdot 12) \dagger$ & $4 \cdot 05(0 \cdot 29)$ & $3 \cdot 46(0 \cdot 16)$ \\
HDL cholesterol & $0 \cdot 81(0 \cdot 04) \dagger$ & $1 \cdot 31(0 \cdot 13)$ & $1 \cdot 18(0 \cdot 06)$ \\
\hline
\end{tabular}

Significantly different from control values: ${ }^{\star}=\mathrm{p}<0 \cdot 05$, $t=p<0.005, \ddagger=p<0.0005$.

The laboratory normal range (5th-95th centile) and mean serum total cholesterol values for an age matched cohort for men is $4 \cdot 08$ $7.08 \mathrm{mmol} / \mathrm{l}$ (mean: $5 \cdot 44 \mathrm{mmol} / \mathrm{l}$ ) and for women is $4 \cdot 42-7 \cdot 83$ $\mathrm{mmol} / \mathrm{l}$ (mean: $5.89 \mathrm{mmol} / \mathrm{l}$ ). The laboratory range and mean serum triglyceride values for an age matched cohort for men is $0.64-3.01 \mathrm{mmol} / \mathrm{l}$ (mean: $1.51 \mathrm{mmol} / \mathrm{l}$ ) and for women is 0.68 $2.74 \mathrm{mmol} / 1$ (mean: $1.47 \mathrm{mmol} / \mathrm{l})$.

TABLE III Mean (SEM) serum cholesterol concentrations (mmolll) according to tumour grade and stage

\begin{tabular}{|c|c|c|c|}
\hline & \multicolumn{3}{|c|}{ Differentiation } \\
\hline & Poor & Moderate & Well \\
\hline \multicolumn{4}{|l|}{ Men: } \\
\hline All stages & $3.89(0.34)$ & $3.73(0 \cdot 15)$ & $3.96(0.27)$ \\
\hline Stages A \& B & $3 \cdot 77$ & $3.65(0.16)$ & $3.93(0.30)$ \\
\hline Stages C \& D & $3.91(0.34)$ & $3.83(0.30)$ & $4.08(0.50)$ \\
\hline \multicolumn{4}{|l|}{ Women: } \\
\hline All stages & $4.31(0.24)$ & $4 \cdot 24(0 \cdot 17)$ & $4.81(0.32)$ \\
\hline Stages A \& B & & $4 \cdot 65(0.30)$ & $4.55(0.25)$ \\
\hline Stages C \& D & $4 \cdot 31(0 \cdot 24)$ & $3.94(0 \cdot 18)$ & $5.59(1.09)$ \\
\hline
\end{tabular}

cholesterol fraction followed the method of Lopes-Virella. ${ }^{26}$ The LDL cholesterol fraction was calculated indirectly using the Friedewald equation. ${ }^{27}$

As blood lipid concentrations change with age and sex, the values were analysed separately for each sex. The reference values for our laboratory for blood lipid values used in this study are shown in Table II and were taken from the American based Lipid Research Clinics. ${ }^{28} 29$ Somewhat comparable standard reference values for an Irish population were available from the 'Mediscan' survey of 15171 men. Mean serum cholesterol values were slightly lower in the American cohorts. ${ }^{16}$ It should be emphasised that, as in all population surveys, 'normal' values represent the normal distribution of cholesterol concentrations and not the 'recommended' or 'healthy normal' concentration.

Analysis of results was performed using the Research Systems Integrated Data Analysis System developed by Bolt, Beranek, and Newman Inc, Cambridge, MA, USA. In all cases, probability values less than 0.05 were taken to indicate significant differences.

\section{Results}

The mean serum lipid concentrations of the colorectal carcinoma, control, and large bowel polyp groups are shown in Table II. The serum triglyceride concentrations of the three groups were similar, all falling within the normal range, but mean total cholesterol, LDL cholesterol, and HDL cholesterol values were significantly lower in the cancer patient group. Mean cholesterol concentrations were significantly higher in women in each study group. Table II also shows that patients with colorectal polyps have lipid profiles similar to the control subjects. The mean total cholesterol concentration among women with polyps was significantly higher than that of control subjects.

When compared with the standard reference values according to the patients' age group, ${ }^{28}$ the individual serum total cholesterol values for men and women were seen to have a propensity to fall within or below the lower end of the normal range. Thirty nine men $(58 \cdot 2 \%)$ and 23 women $(48.9 \%)$ with colorectal carcinoma had total cholesterol values below the 5 th centile of the normal reference range.

Although colorectal carcinoma patients had evidence of low serum cholesterol concentrations, no further lowering of cholesterol or its two major lipoprotein fractions occurred as the disease process spread. There were no significant differences in cholesterol concentrations between patients with stage A and B lesions and those with stage $\mathrm{C}$ and $\mathrm{D}$ lesions (Table III). Furthermore, there were no differences in observed lipid values between tumours for each Astler Coller stage.

When analysed according to tumour differentiation, no significant differences were found between cholesterol concentrations for any combination of well, moderately, and poorly differentiated tumours (Table III). Furthermore, there were no significant differences in cholesterol values with change of tumour grade 
when analysed for stage A and B alone, or for stage $\mathrm{C}$ and $\mathrm{D}$ alone.

There was no biochemical evidence of the patients being nutritionally compromised mean serum albumin $(38.3(1 \cdot 1) \mathrm{g} / \mathrm{l})$ and mean retinol binding protein $(2.5(0.4) \mathrm{mg} / \mathrm{dl})$ values were within the normal range. These biochemical parameters did not differ according to tumour stage or degree of differentiation. Further evidence of the nutritional wellbeing of the patients was provided by serum triglyceride values. Most values (61/67 men (91\%) and 44/47 women $(93.6 \%)$ ) fell within the 5th and 95th centile of the reference population..$^{28}$

\section{Discussion}

Epidemiological data based upon population studies have indicated a positive association between dietary cholesterol and colorectal cancer. ${ }^{3031}$ Furthermore, a strong correlation between the mean concentration of cholesterol in a population and the incidence of coronary heart disease has been noted. Thus, it would be reasonable to expect that populations with a high mortality rate from coronary heart disease would also exhibit a high mortality rate for colon cancer. Using WHO national mortality rates for both colonic cancer and coronary heart disease, Rose $e t a l^{5}$ showed a direct relation between these two diseases, and on the basis of this finding anticipated that serum cholesterol values could be used as a predictor of colon cancer. Contrary to these expectations, Rose found that in a group of 36211 men followed from 5 to 23 years, two thirds of those who developed colon cancer had initial serum cholesterol values below the age sex specific values for each respective cohort. ${ }^{5}$ Since then, numerous studies have analysed the relation between serum cholesterol and large bowel cancer. Low values have been attributed by some authors to a preclinical effect of the tumour, ${ }^{32}{ }^{33}$ others have shown that the lowered values predate the detection of cancer by at least five years..$^{3435}$ This latter finding implies that the hypocholesterolaemia is unlikely to have been caused by the metabolic effect of an occult tumour.

Other studies have failed to show a relation between serum cholesterol and colorectal carcinoma..$^{36}$ One major prospective study has shown a direct relation in men between serum cholesterol and the incidence of rectal carcinoma alone. ${ }^{12}$ Nevertheless, it is difficult to compare directly these various studies as there are appreciable differences in the range of cholesterol values found, age and ethnic origins of the patients, methodology, and the case distribution of the populations studied.

This Irish study has indicated that most patients with colorectal carcinoma have low serum cholesterol values. Cholesterol values were in the lower part of the normal range for the 114 cancer patients in the appropriate sex and age matched groups. About half the patients had concentrations below the lower end of the reference range. Interestingly, both female as well as male patients exhibited a hypocholesterolaemia, a finding not previously reported among other population groups. In a similar study conducted in another Dublin hospital, O'Morain et al also described high serum cholesterol values among 57 patients with adenomatous colonic polyps as well as significantly lower serum cholesterol values among 49 patients with colorectal cancer. ${ }^{38}$

It has been reported that serum cholesterol values are similar in samples from fasting and non-fasting subjects. ${ }^{39}{ }^{40}$ Because of the rigorous nature of fasting and bowel preparations before surgical resection of tumours, it seemed possible that these procedures could contribute to the hypocholesterolaemiac state. The finding of normal cholesterol values in the group of patients undergoing similar preparation before colonoscopy, eliminated the preparatory protocol as a contributor to the lowered cholesterol values. The finding of normal concentrations of albumin, retinol binding protein, and triglyceride among cancer patients, irrespective of the stage and tumour grade, excludes nutritional wasting as a cause of the hypocholesterolaemia.

In agreement with previous studies, ${ }^{36+1}$ the serum cholesterol concentrations for the patients with colorectal adenomas were similar to, or, as in the case of women, higher than those of the control group. The cancer subgroup, even those with very early tumours, had significantly lower cholesterol values than the group with polyps alone.

In this study there was no significant difference in serum cholesterol concentrations of total, LDL, and HDL cholesterol in samples taken from patients with early and late disease. Furthermore, there were no differences in serum cholesterol values in patients with different tumour grades. If the lowering of serum cholesterol values was the result of tumour activity, obvious differences in serum cholesterol values as the tumours progressed from stage A to stage $\mathrm{D}$, or as they become more dedifferentiated would have been expected. Our findings agree with those of the Honolulu Heart Study which found that the inverse relation between serum cholesterol values and colon cancer was independent of the pathological stage of the carcinoma. ${ }^{3+}$ These results are in contrast with the New York Case Control Study which showed that cholesterol values in patients with advanced colorectal carcinomas were significantly different from those of controls but this was not so for early disease. ${ }^{42}$ Our findings suggest that tumour activity is not a major cause of the lowered serum cholesterol values seen in most of our patients.

If the hypocholesterolaemia among colorectal cancer patients is not caused by a metabolic effect of the tumours, how can such a phenomenon be explained? Upon consideration of the hypothesis that bile constituents and their intracolonic degradation products influence colon carcinogenesis, ${ }^{43+4}$ it has been proposed that subjects with a metabolic predisposition towards lowered serum cholesterol may also have an increased secretion of bile and hence an increased risk of developing colorectal carcinoma. ${ }^{+5}$ Thus, the carcinogenic effects of a high consumption of dietary fat may be more readily produced in subjects who maintain lowered cholesterol concentrations by showing an inherently greater 
conversion rate to bile acids than the rest of the population. Such a hypothesis could explain the paradoxical inverse relation between serum cholesterol concentrations and colorectal carcinomas detected in certain western, or at least 'westernised' populations.

The association seen in our study may be the result of a shared phenotype in patients prone to develop the disease. Alternatively, it may represent a subgroup of people with a genetically different cholesterol metabolism, which under particular dietary or environmental circumstances - for example a high fat, low fibre diet would indirectly promote colon carcinogenesis. Future analyses, including a study of the lipid phenotypes of patients with colorectal carcinoma, may yield data in support of such a hypothesis.

In conclusion, Irish patients with colorectal carcinoma exhibit a noticeable hypocholesterolaemia that does not seem to be the result of a compromised nutritional state.

1 Waterhouse J, Muir C, Shanmugaratnam K, Powell J, eds. Cancer incidence in five continents. Vol IV. IARC Sci Publ No 42. Lyon: IARC, 1982.

2 Wynder EL, Graham S, Eisenberg H. Conference on the etiology of cancer of the gastrointestinal tract. Report of the research committee on gastroenterology. WHO. Cancer research committee

3 Burkitt DP. Epidemiology of cancer of the colon and rectum. Cancer 1971; 28: 3-13.

4 Reddy BS, Wynder EL. Large bowel carcinogenesis: fecal constituents of populations with diverse incidence rates of colon cancer. F Natl Cancer Inst 1973; 50: 1437-42.

5 Rose G, Blackburn H, Taylor HL, Keys A, Kannel WB, Pau $\mathrm{O}$, et al. Colon cancer and blood cholesterol. Lancet 1974; $\mathrm{i}$ 181-3.

6 Hjermann I, Velve Byre K, Holme I, Leren P. Effect of diet and smoking intervention on the incidence of coronary heart disease. Lancet 1981; ii: 1303-10.

7 Lipid Research Clinics Program. The LRC coronary primary prevention results. II. The relationship of reduction in prevention results. In. The relationship of reduction in incidence of coronary heart

8 Isles CG, Hole DV, Gillis CR, Hawthorne VM, Lever AF. Plasma cholesterol, coronary heart disease, and cancer in the Penfrew and Paisley survey. BMF 1989; 298: 920-4.

9 Pocock SJ, Shaper AG, Phillips AN. Concentrations of high density lipoprotein cholesterol, triglycerides, and total cholesterol in ischaemiac heart disease. BMF 1989; 298 998-1002.

10 Dyer AR, Stamler J, Paul O, et al. Serum cholesterol and risk of death from cancer and other causes in three Chicago epidemiological studies. F Chronic Dis 1981; 34: 249-60.

11 Westlund $\mathrm{K}$, Nicolaysen $\mathrm{R}$. Ten year mortality and morbidity related to serum cholesterol: a follow-up of 3751 men age 40-49. Scand f Clin Lab Invest (suppl) 1972;127 1-24.

12 Tornberg SA, Holm L-E, Carstensen JM, Eklund GA. Kısks of cancer of the colon and rectum in relation to serum of cancer of the colon and rectum in relation to serum
cholesterol and beta-lipoproteins. N Engl F Med 1986; 315: 1629-33.

13 Feinleib $M$. On a possible inverse relationship between serum cholesterol and cancer mortality. Am $\mathcal{F}$ Epidemiol 1981; 114 5-10

14 Kagan A, McGee DL, Yano K, Rhoads GG, Nomura A Serum cholesterol and mortality in a Japanese-American population. Am f Epidemiol 1981; 114: 11-20.

15 Kark JD, Smith AH, Switzer BR, Hames CG. The relationship of serum cholesterol to the incidence of cancer in Evans County, Georgia. 7 Chronic Dis 1980; 33: 311-22.

16 Hickey N, Mulcahy R, Bourke GJ, Graham I, Wilson-Davis $\mathrm{K}$. Study of coronary risk factors related to physical activity K. Study of coronary risk factors rela
in 15171 men. $B M F 1975 ; 3: 507-9$.

17 Habba SF, Daly L, Doyle JS. An update on the Irish and international mortality from cancer of the intestine and rectum. Ir f Med Sci 1983; 152: 119-20.
18 Sachs E, Bernstein LH. Protein markers of nutritional status as related to sex and age. Clin Chem 1986; 32: 339-41

19 Clark RG, Karatzas T. Pre-operative nutritional status. $\mathrm{Br}$ Clin Prac 1988; 63 (Symp suppl): 2-7.

20 Fleck A. Plasma proteins as nutritional indicators in the perioperative period. Br F Clin Prac 1988; 63 (Symp suppl): $20-4$.

21 Astler VB, Coller FA. The prognostic significance of direct extension of carcinoma of colon and rectum. Ann Surg 1954; 139: $846-51$.

22 Dukes CE. The classification of cancer of the rectum. 7 Pathol Bacteriol 1932; 35: 323-32.

23 Blenkinsopp WK, Stewart-Brown S, Blesovsky L, Kearney G Fielding LP. Histopathology reporting in large bowel cancer. F Clin Pathol 1981; 34: 509-13.

24 Wahlefeld AW. Triglycerides. Determination after enzymatic hydrolysis. In: Bergmeyer HU, ed. Methods of enzymatic analysis. 2nd English ed. New York, London: Verlag Chemie Weinheim and Academic Press, 1974: 1831.

25 Roschlau P, Bernt E, Gruber W. Enzymatic determination of total cholesterol in serum using peroxidase as the indicating system. $\mathcal{F}$ Clin Chem Clin Biochem 1974; 12: 226

26 Lopes-Virella MF, Stone P, Ellis S, Colwell JA. Cholesterol determination in high density lipoproteins separated by three different methods. Clin Chem 1977; 23: 882-4.

27 Friedewald WT, Levy RI, Fredrickson DS. Estimation of the concentration of low-density lipoprotein cholesterol in plasma, without use of the preparative ultracentrifuge. Clin Chem 1972; 18: 499-502.

28 The Lipid Research Clinics Program Epidemiology Committee. Plasma lipid distributions in selected North American populations: The Lipid Research Clinics Program Prevalence Study. Circulation 1979; 60: 427-39.

29 Heiss G, Tamir I, Davis CE, et al. Lipoprotein-cholestero distributions in selected North American populations: The Lipid Research Clinics Program Prevalence Study. Circulation 1980; 61: 302-15.

30 Drasar BE, Irving D. Environmental factors and cancer of the colon and breast. BrF Cancer 1973; 27: 167-72.

31 Armstrong B, Doll R. Environmental factors and cancer incidence and mortality in different countries, with special incidence and mortality in different countries, with special

32 Rose G, Shipley MJ. Plasma lipids and mortality: a source of error. Lancet 1980; i: 523-6.

33 Gerhardsson M, Rosenqvist U, Ahlbom A, Carlson L. Serum cholesterol and cancer, a retrospective case-control study Int $\mathcal{F}$ Epidemiol 1986; 15: 155-9.

34 Stemmermann GN, Nomura AMY, Heilbrun LK, Pollack ES, Kagan A. Serum cholesterol and colon cancer incidence in Hawaiian Japanese men. $\mathcal{f}$ Natl Cancer Inst 1981; 67: 1179-82.

35 Williams RR, Sorlie PD, Feinleib M, McNamara PM, Kannel WB, Dawber TR. Cancer incidence by levels of cholesterol and other variables from the Framingham data. $\mathcal{F} A M A$ 1981; 245: 247-52.

36 Neugut AI, Johnsen CM, Fink DJ. Serum cholesterol levels in adenomatous polyps and cancer of the colon. A case-control adenomatous polyps and cancer of
study. FAMA 1986; 255: 365-7.

37 Sidney S, Friedman GD, Hiatt RA. Serum cholesterol and large bowel cancer: a case control study. Am $\mathcal{F}$ Epidemiol 1986; 124: 33-8.

38 O'Sullivan KR, Mathias PM, Tobin A, O'Morain C. Risk of adenomatous polyps and colorectal cancer in relation to serum antioxidants and cholesterol status. Euro $\mathcal{f}$ Hepatol Gastroenterol (in press).

39 Lipid Research Clinics Program. Manual of laboratory operations. Vol I. Lipid and lipoprotein analysis. DHEW publication (NIH). Bethesda, USA: National Institutes of Health, 1974: 76-628.

40 National Center for Health Statistics: National Heart, Lung and Blood Institute Collaborative Group. Trends in serum cholesterol levels among US adults aged 20 to 74 years. FAMA 1987; 257: 937-42.

41 Mannes GA, Maier A, Thieme C, Wiebecke B, Baumgartner $\mathrm{G}$. Relation between the frequency of colorectal adenoma and the serum cholesterol level. N Engl f Med 1986; 315: $1634-8$

42 Miller SR, Tartter PI, Papatestas AE, Slater G, Aufses AH Jr. Serum cholesterol and human colon cancer. 7 Natl Cancer Institute 1981; 67: 297-300.

43 Hill MJ, Drasar BS, Williams REO, et al. Faecal bile acids and clostridia in patients with cancer of the large bowel. Lancet 1975; i: 535-9.

44 Reddy BS, Wynder EL. Metabolic epidemiology of colon cancer. Cancer 1977; 39: 2533-9.

45 Lowenfels $\mathrm{AB}$. Is increased cholesterol excretion the link between low serum cholesterol and colon cancer? Nutr Cancer 1983; 4: 280-4. 